\title{
amelanotic melanoma
}

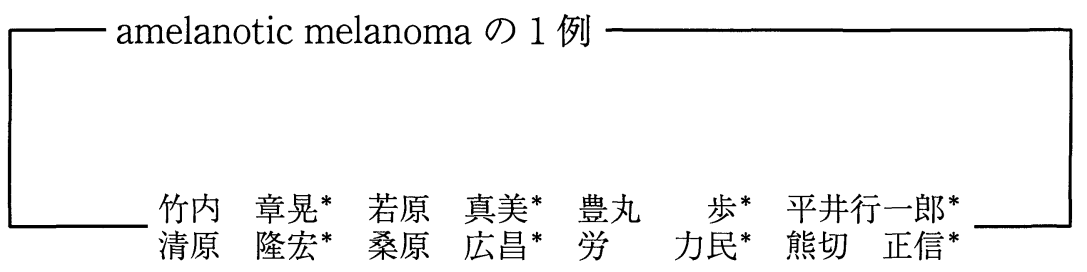

\begin{abstract}
A case of amelanotic melanoma
Akiteru TAKEUCHI, Mami WAKAHARA, Ayumi TOYOMARU, Kouichirou HIRAI, Takahiro KIYOHARA, Hiroaki KUWAHARA, Li-Min Lao, Masanobu KUMAKIRI

Summary : We report a case of amelanotic melanoma. A 56-year-old man had noticed a small nodule on his right medial plantar aspect of the foot about one year previously. Although he had tried to remove the nodule by pricking with a pin, it had continued to grow.

When he visited our hospital on September 2, 1998, the dome-shaped nodule measured $20 \times 18 \mathrm{~mm}$. On closer examination, a small pigmented macule was observed in the periphery of the nodule. The right inguinal lymph nodes were swollen.

We excised the tumor with the presumptive diagnosis of squamous cell carcinoma or eccrine porocarcinoma, since the pigmented macule was faint that the diagnosis of melanoma could not be considered. Wide local excision (2cm margin) and inguinal lymph node biopsy were performed. However, the histopathological diagnosis was malignant melanoma, and lymph node biopsy revealed metastasis of melanoma(pT4aN1M0, Breslow's thickness 4.6mm, Clark level V , Stage III ). Right inguinal lymph node dissection and chemotherapy were added. Electronmicroscopic study revealed many melanosomes in the melanoma cells and confirmed the diagnosis. Amelanotic melanoma should be considered when a red nodule on the foot is examined. [Skin Cancer (Japan) 2000; 15:53-56]
\end{abstract}

Key words : Amelanotic melanoma, Electron-microscopic findings, Vitiligo

\section{はじめに}

amelanotic melanomaは臨床的には無色素 性, すなわち紅色の腫瘍で, 光顕的にもメラニ ン形成が全くないか, または少なく, 確定診断

* 福井医科大学皮膚科
は切除後になされることが多い。今回我々は, 右内側足底部の amelanotic melanoma の 1 例を 経験したので報告する。

\section{症例}

症 例: 56 歳, 男性, なわ職人

初 診: 1998 年 9 月 2 日 
主 訴：右内側足底部の腫瘤

家族歴：特記事項はない。

既往歴：重度心身障害

現病歴：初診の 1 年程前, 右内側足底部に腫 瘤が出現したことに気付いたようである。当初 は小豆大の大きさであったが，除去しょうとし て針を刺していたところ, 1998 年 5 月頃には大 きさが増し，隆起して目立つようになり，親族 に連れられて福井医科大学皮膚科を受診した。

現 症: 右内側足底部に大きさ $20 \times 18 \mathrm{~mm}$ の 境界明暸で, 辺縁に一部黒色斑を伴った肉芽腫 様の腫瘤を認めた（図１）。また右鼠径部にはリ ンパ節腫張がある。

検査所見：頭部，胸部，腹部，骨盤 CT では 多藏器への転移の所見はなかった。Ga シンチ において，右鼠径部のリンパ節に uptakeを認め たが，原発巣および他の部位の uptakeはなかっ た。右足部の MRI では, 腫瘍は真皮層までで筋
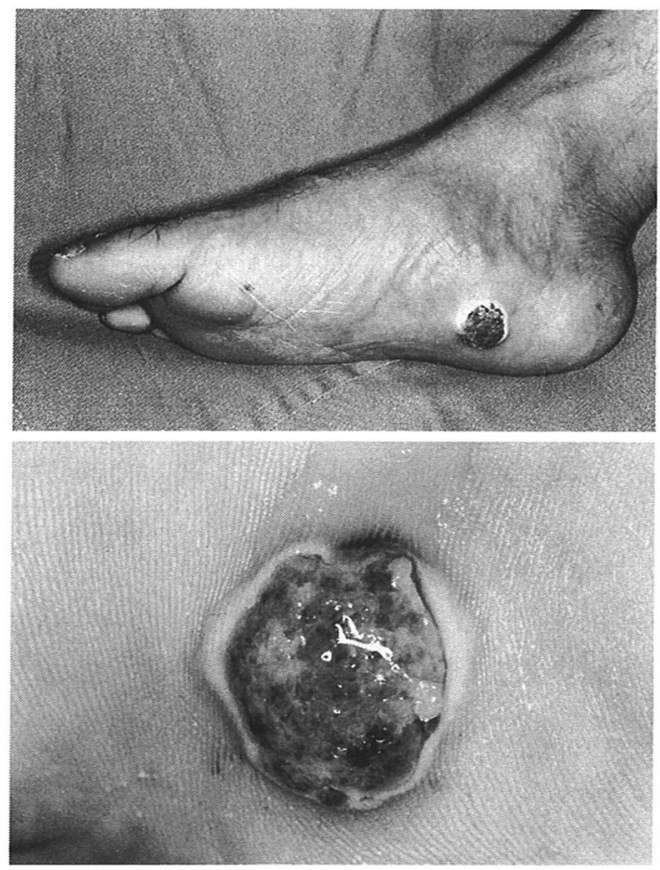

図 1 ．入院時所見

右内側足底部に大きさ $20 \times 18 \mathrm{~mm}$, 境界明膫 で辺縁に一部黒色斑を伴った肉芽腫様の腫瘤
膜，骨への浸潤は認めなかった。

治療経過：有棘細胞癌や汗腺系の悪性腫瘍を 疑い, 1998 年 9 月 17 日広範囲切除㧍よび右鼠 径部リンパ節生検を行った。腫瘍は $20 \mathrm{~mm}$ 以上 離して，筋膜を含めて切除し，分層植皮を行っ た。病理組織診断は悪性黒色腫で，鼠径リンパ 節生検では転移を認めた $\left(\mathrm{pT}_{4 \mathrm{a}} \mathrm{N}_{1} \mathrm{M}_{0}\right.$, Breslow's thickness 4.6mm, Clark level V , Stage III )。

診断が確定したためフェロンの局注（300万 単位 / 10 日間) を行った後, 10 月 15 日右鼠径. 後腹膜リンパ節郭清を行った。リンパ節は 19/24で転移を認め，外腸骨リンパ節にも転移 を認めた。11月17日よりシスプラチン 20mg/ 5 日間, ダカルバジン 150mg/ 5 日間, ビ ンデシン $3 \mathrm{mg} / 1$ 日間, フェロン 300 万単位/ 10 日間の化学療法を 1 クール行った。当初は 2 クール行う予定であったが骨髄機能抑制の副作 用が遷延したため行えなかった。

現在, 術後 6 力月を経過しているが, 再発や 転移の所見はない（図２）。今後さらに化学療法 を施行する予定である。

病理組織学的所見：腫瘍細胞は核の大小不 同，異型性が著明で真皮深層まで浸潤してお り，一部は皮下にまで達していた（図３）。電顕 所見では，黒色腫細胞はケラチノサイト間に胞 巣を形成して増殖・浸潤し，また基底層に相接 して増殖していた。核は軽度に切れ込みがあ

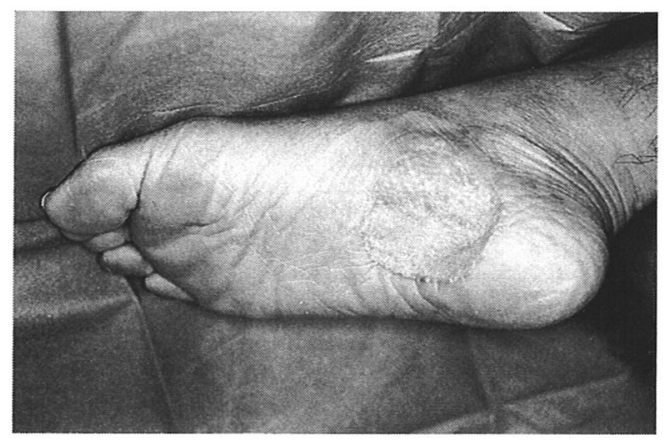

図 2. 術後 6 力月の状態 再発や転移はみられない 
り，あるいは分葉状であった。空胞化したミト コンドリアが豊富で粗面小胞体は少なかった。
メラノゾームは類円形のものが多く，内部には 微細粒子がみられた（図４）。

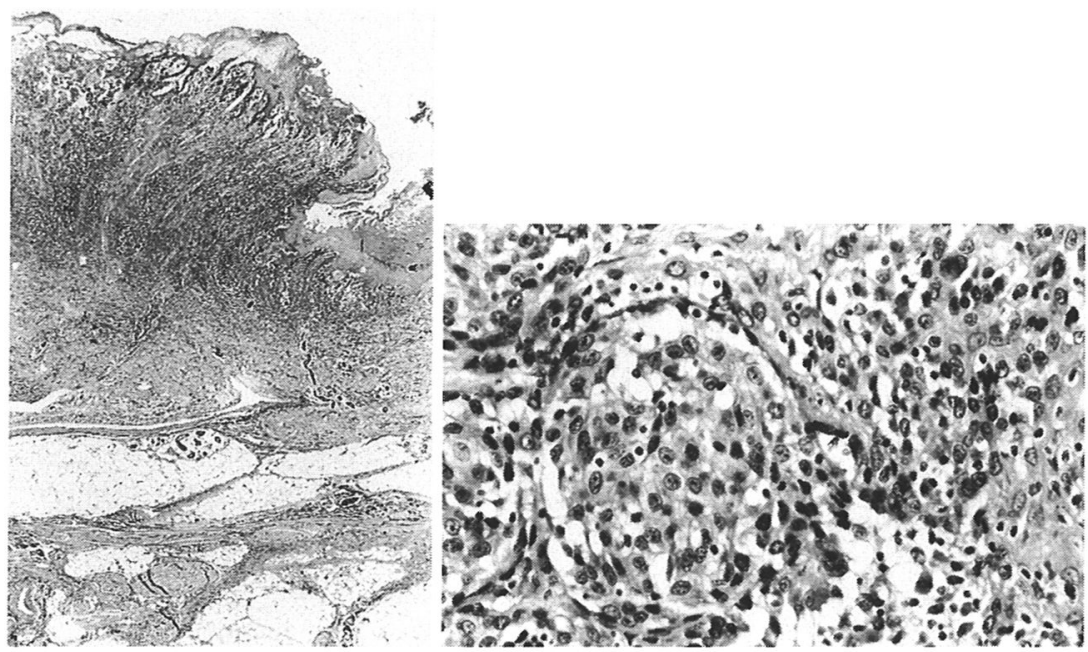

図 3.病理組織像 (H.E. 染色)

腫瘍細胞は核の大小不同，異型性が著明で真皮深層まで浸潤する
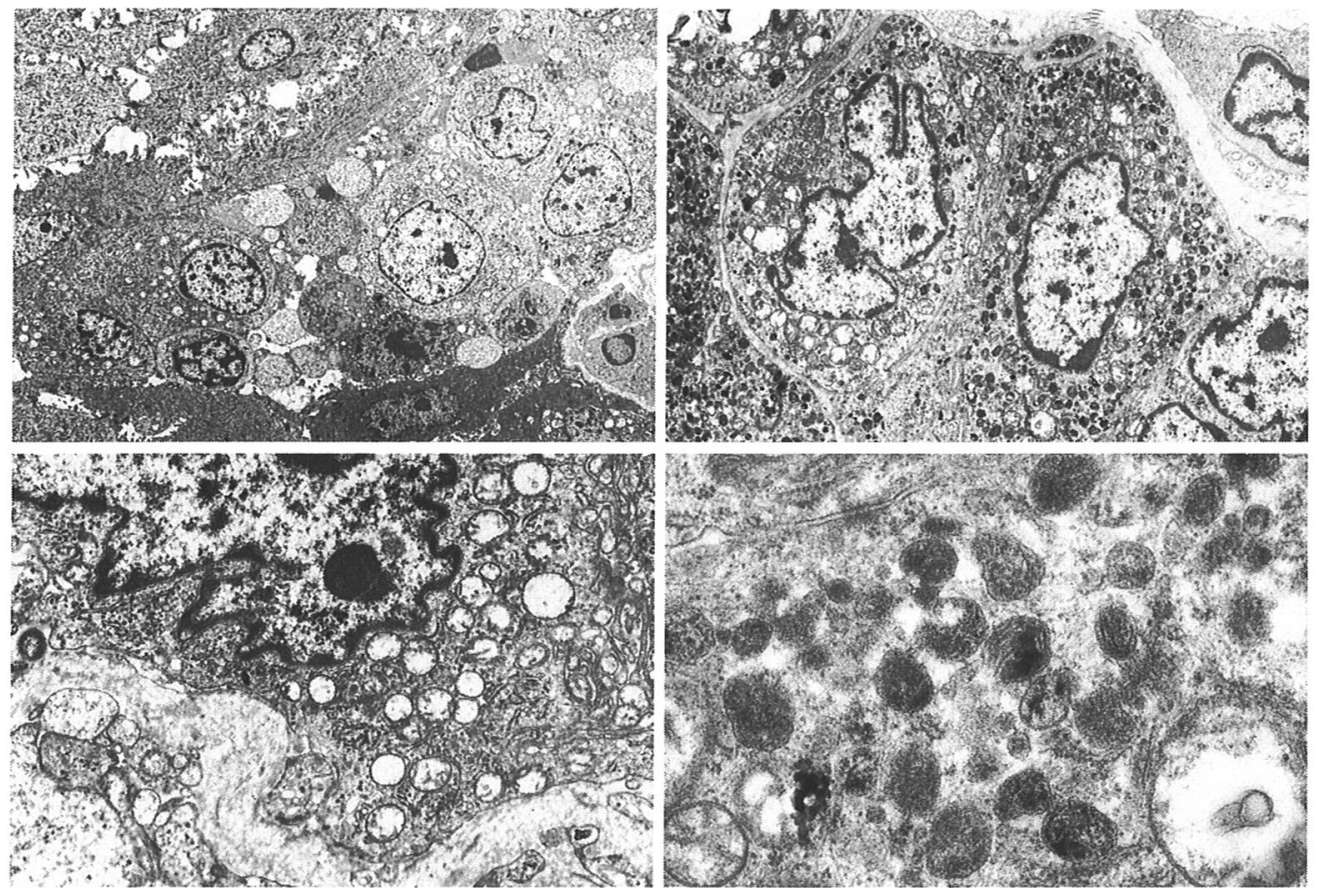

図 4a. 黒色腫細胞はケラチノサイト間に胞巣を形成して増殖・浸潤している（電顕所見 $\times 2,500 ） a \mid b$

b. 黒色腫細胞は基底層に相接して増殖している. 核は軽度に切れ込みがあり，あるいは分葉状 $\mathrm{c} \mid \mathrm{d}$ である(電顕所見 $\times 7,000)$

c. 空胞化したミトコンドリアが豊富で粗面小胞体は少ない（電顕所見 $\times 9,000 ）$

d. メラノゾームは類円形のものが多い.内部には微細粒子がみられる（電顕所見 $\times 40,000 ）$ 


\section{考察}

無色素性悪性黒色腫 (AMM) は，一般に術前 診断が困難で，そのため部分生検が行われた り, 良性腫瘍として切除され, 病理診断で初め て悪性黒色腫と確認される症例が多い。あるい は肉芽腫や胼胝腫として電気焼灼や腫瘍を削る 治療をされた後に確定診断が下されることもあ る ${ }^{1)}$ 。一般的に, amelanotic type が melanotic

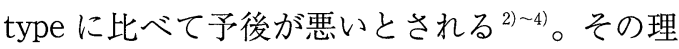
由として AMM は診断の誤りや, 不適切な初期 治療に一因があると考えられている。しかし， 一方では AMM は，より低分化性の腫瘍である という考えもある ${ }^{5}$ 。いずれにせよ，臨床診断 の難しい腫瘍であり，足底の腫瘍は AMM を常 に念頭におき注意深く観察することが必要のよ うである。なお加藤ら ${ }^{6)}$ によると悪性黑色腫の 好発部位は手足が 150 例中 84 例で，うち足底 47 例，爪甲下 22 例となっている。また杉原ら の報告でも足底が 100 例中 31 例で最も多い。

我々が経験した症例は，腫瘍辺縁にわずかに 黒色を呈する部分がみられたが，主病変は紅色 の肉芽様であり，わずかに観察された色素斑も 悪性黒色腫の色調とは考え難かった。当初は有 棘細胞癌や汗腺系の悪性腫瘍を疑った。また患 者も病識に欠け, 病歴で初期には黒色の腫瘍で あったかどうかを聴取することができなかっ た。しかも当科を受診するまでの約 1 年の間に 腫瘤を針で刺しており，腫瘍を腫瘤の拡大やリ ンパ節転移を助長した可能性が高い。

ただ，病理組織学的には原発巣にも，メラ ニンは存在し，また電顕所見においても不十分 にメラニン化したメラノゾームがみられた。ま たリンパ節にはメラニンが多く含まれていた。

本症例は手術後，臀部，背部，下顎部，右鼠 径部, そして原発巣である右内側足底部の植皮 部周囲の皮膚に白斑が出現し，拡大している。 白斑の出現は予後良好な兆候ともいわれている
が 8) -10)，注意深く経過観察していく予定であ る。

\section{まとめ}

今回我々は, 右内側足底部の amelanotic melanomaの 1 例を経験した。amelanotic melanoma は診断の際に誤診されやすく，常に 鑑別診断の際に念頭において診断，治療に当た る必要がある。

\section{文献}

1) 麻生和雄, 穂積豊 : Amelanotic malignant melanoma の 1 例。臨皮, 38:171-177, 1984.

2) Shah, J. P. : Amelanotic melanoma. Prog. Clin. Cancer, 6 : 195-197, 1975.

3) Hubous, A. G., Shah, J. P. Goldsmith, H. S. : A clinicopathologic study of amelanotic melanoma. Surg. Gynecol. Obstet., 135: 917-920, 1972.

4) Balch, C. M. , Murad, T. M. , Soong, S. J. , et al. : A multifactorial analysis of melanoma prognostic histopathological features comparing Clark's and Breslow's staging methods. Ann. Surg. , 188 : $732-$ 742, 1978

5) Bhawan, J. : Amelanotic melanoma or poorly differentiated melanoma ? J. Cutan. Pathol., 7 : 55$56,1980$.

6）加藤泰三，末武茂樹，杉山泰子，他：悪性黑色腫 20 年間の推移一東北大学皮膚科 150 例の観察 一。臨皮, $46: 327-330,1992$.

7）杉原平樹，吉田哲憲，国分一郎，他：悪性黒色腫 一自験 100 例における TNM 分類と予後一。日 形会誌, $14: 355-364,1994$.

8) Bystryn, J. C. , Rigel, D. , Friedman, R. J. , et al. : Prognostic significance of hypopigmentation in malignant melanoma. Arch. Dermatol., 123 : 10531055, 1987.

9) Nordlund, J. J. , Kirwood, J. M. , Forget, B. M. , et al. : Vitiligo in patient with metastatic melanoma; A good prognostic sign. J. Am. Acad. Dermatol., 9 :689-696, 1983.

10）舟山恵美，杉原平樹，国分一郎，他：原発巣の完 全自然消退を呈し沉発性白斑症を合併した悪性黒 色腫の 1 例。形成外科, 39:1139-1148, 1996. 